\title{
ANALISIS PENGGUNAAN APLIKASI "yesHeis" DALAM PENGINJILAN PRIBADI
}

\author{
Steaven Octavianus \\ Sekolah Tinggi Teologi Sangkakala \\ Jl. Raya Kopeng, Sumogawe, Getasan, Semarang, Jawa Tengah 50774 \\ steavenoctavianus@sttsangkakala.ac.id
}

\begin{abstract}
Steaven Octavianus, Analysis of Use of "yesHeis" Applications In Personal Evangelism. The globalization era and the advancement of science and technology as well as the internet made great impact to human life. This advancement also has an impact on the Christian evangelical life. In carrying out the Great Commission of the Lord Jesus, Christians can use this opportunity. However, this should still be managed and supervised wisely. This study will look at the use of the "yesHeis" app in sharing videos on social media Facebook and the responses of Christians about the app. This research will use qualitative approach with descriptive analysis method. Based on this research many people give positive response on this application. Even though many people positively respond to this app they are still hesitant to share it and even install it on their smart phone.
\end{abstract}

Keywords: Personal Evangelism, "yesHeis" App, Response

\begin{abstract}
Abstrak: Steaven Octavianus, Analisis Penggunaan Aplikasi “yesHeis” Dalam Penginjilan Pribadi. Era globalisasi dan kemajuan ilmu pengetahuan dan teknologi serta internet membawa dampak yang besar bagi kehidupan manusia. Kemajuan ini juga berdampak dalam kehidupan penginjilan pribadi umat Kristiani. Dalam melaksanakan Amanat Agung Tuhan Yesus umat Kristen dapat menggunakan kesempatan kemajuan ini. Namun begitu hal ini tetap harus dikelola dan diawasi dengan bijaksana. Penelitian ini akan melihat penggunaan aplikasi "yesHeis" dalam membagikan video di media sosial Facebook serta tanggapan dari orang Kristen mengenai aplikasi tersebut. Penelitian ini akan menggunakan pendekatan kualitatif dengan metode analisis deskriptif. Berdasarkan penelitian ini banyak masyarakat yang memberikan respon positif atas aplikasi ini. Namun walaupun banyak orang secara positif merespon aplikasi ini mereka masih ragu untuk membagikan bahkan menginstalnya di telepon pintarnya.
\end{abstract}

Kata Kunci: Penginjilan Pribadi, Aplikasi “yesHeis”, Respon

\section{PENDAHULUAN}

Penginjilan berasal dari bahasa Latin "Evangelium", yang berasal dari bahasa Yunani "eu" yang berarti baik/sehat dan "aggelos" yang berarti utusan (Macaulay \& Belton, 1956, p. 1). Wijaya dan Darmawan (2016, p. 52) mengungkapkan bahwa penginjilan merupakan tugas setiap orang yang percaya kepada Yesus Kristus sebagai Juruselamat pribadinya. Memberitakan Kabar Baik/Injil merupakan amanat agung bagi orang Kristen yang tertulis dalam Kitab Injil. Menurut Diaz (2014, p. 42) misi ini merupakan isi hati Allah dan mandat yang berkelanjutan bagi setiap orang Kristen. Berdasarkan hal itu maka penginjilan ini tidak hanya berhenti untuk para murid saja namun juga berlaku bagi seluruh umat Kristen. Lebih lanjut Diaz (2014, p. 30) menyatakan bahwa penginjilan merupakan tanggungjawab dan kehormatan bagi orang percaya. Dengan adanya hal itu maka seharusnya orang percaya memiliki motivasi lebih besar dalam melakukan penginjilan dalam kehidupannya. Jika penginjilan merupakan amanat agung dan kehormatan, maka sudah tentu penginjilan pribadi adalah hal yang harus dilakukan oleh orang percaya. Dalam bukunya Sawadogo (1978, p. 5) menyatakan bahwa penginjilan pribadi terjadi setelah orang Kristen menerima Yesus sebagai Tuhan dan Juruselamat. Lebih lanjut Sawadogo (1978, p. 5) menyatakan bahwa penginjilan pribadi merupakan sebuah peristiwa ketika seseorang menceritakan pengalaman pribadinya dengan Yesus dan kuasa-Nya yang menyelamatkan. Berdasarkan pada uraian tersebut maka penginjilan 
pribadi merupakan amanat agung dan kehormatan yang menjadi bagian dari gaya hidup orang percaya. Menurut Objantoro (2017, p. 129) kaum Injili keyakinan yang kuat bahwa penginjilan merupakan keharusan untuk diberitakan. Penginjilan pribadi merupakan sebuah momen dimana orang percaya membagikan pengalaman hidupnya dengan Yesus dan kabar keselamatan-Nya. Penginjilan pribadi dapat terjadi setelah seseorang menerima Yesus sebagai Tuhan dan Juruselamat dan menjadi orang percaya. Dengan begitu barulah penginjilan pribadi dapat dilakukan (Sawadogo, 1978, p. 5). Seperti juga amanat agung yang tertulis dalam kitab suci Injil maka penginjilan pribadi bukan hanya sebuah pilihan namun adalah sebuah kewajiban yang signifikan bagi orang Kristen. Melihat dari pembahasan yang dipaparkan oleh Sawadogo dan Diaz maka elemen utama dalam penginjilan pribadi adalah membagikan cerita. Dengan membagikan cerita mengenai kehidupan pribadi seorang percaya dengan Tuhan Yesus maka terjadilah sebuah penginjilan pribadi.

Perkembangan ilmu pengetahuan dan teknologi internet memberikan banyak pengaruh dalam kehidupan masyarakat khususnya generasi muda (Sumolang, 2013). Kemajuan teknologi dan informasi internet membuka banyak kesempatan bagi orang Kristen untuk melaksanakan amanat agung yang diberikan oleh Tuhan Yesus Kristus. Namun demikian penggunaan media internet ini harus terus dikaji dan diawasi dalam praktiknya. Penelitian mengenai penggunaan media internet sebagai media penginjilan telah dilaksanakan oleh Pasasa (2015, p. 71). Dalam penelitiannya Pasasa menemukan bahwa kemajuan teknologi di era globalisasi ini menyediakan peluang bagi orang Kristen untuk melakukan penginjilan. Media internet dapat menjadi salah satu alternatif untuk melaksanakan amanat agung ini. Namun walaupun media internet menawarkan banyak keunggulan dan peluang, Pasasa (2015, p. 97) menyatakan bahwa hal ini tidak dapat menggantikan kontak langsung dengan personal yang merupakan hakikat penginjilan pribadi. Dalam penelitiannya Pasasa hanya menganalisis media internet secara luas, namun dalam penelitian ini peneliti akan melihat salah satu aplikasi yang ada di media sosial dan media internet secara khusus.

Dewasa ini penggunaan internet maupun media sosial merupakan hal yang wajar dan biasa. Penggunaan media sosial dan internet di perangkat pintar pun juga merupakan sebuah kewajaran dan kebiasaan di masyarakat kita. Dari data terakhir penggunaan internet pada telepon pintar pada tahun 2017 sudah mencapai 3.4 miliar pengguna di seluruh dunia (https://www.youthmanual.com/). Jumlah yang cukup besar dan artinya penggunaan internet melalui gawai khususnya telepon pintar sudah menjadi suatu hal yang biasa dan umum. Kini masyarakat dapat mengakses internet secara mudah melalui gawainya tanpa harus melalui komputer maupun laptop.

Indonesia sebagai negara berkembang dan dengan populasi kaum muda yang banyak juga memiliki andil besar dalam penggunaan internet tersebut. Menurut e-Marketer seperti dikutip pada laman internet kominfo dikatakan bahwa netter Indonesia berjumlah 112 juta orang pada tahun 2017 mengalahkan Jepang (Wicaksono, 2014). Selanjutnya masih dalam laman yang sama penggunaan ponsel dan broadband mobile yang murah mendukung pertumbuhan penggunaan internet di negara berkembang seperti Indonesia. Dengan tingginya penggunaan internet melalui gawai di Indonesia membuktikan bahwa internet bukan lagi barang mahal dan eksklusif bagi sebagian orang, namun lebih merupakan sebagi hal yang umum dan biasa. Tingginya angka penggunaan internet menyebabkan perubahan dalam kehidupan sosial. Penggunaan internet tentu saja akan terus bertumbuh (Wicaksono, 2014). Dampak yang dihasilkan pun bukan hanya dampak negatif melainkan dampak yang juga positif (Pasasa, 2015).

Berdasarkan pada perkembangan internet dan penggunaannnya pada gawai umat Kristen di Indonesia dapat memanfaatkannya sebagai media dalam penginjilan pribadi. Penginjilan merupakan amanat agung yang disampaikan oleh Tuhan Yesus melalui kitab Injil Matius 28:19,20; Markus 16:15. 
Amanat agung ini tidak hanya berlaku pada zaman dimana kitab Injil ditulis saja namun berlaku sampai dengan sekarang ini. Untuk itu berdasarkan Kitab Injil tersebut pengkabaran Injil bagi umat Kristen merupakan sebuah amanat yang langsung diperintahkan oleh Tuhan Yesus sendiri.

Penelitian mengenai pemanfaatan media internet sebagai media pemberitaan Injil telah dilakukan oleh Pasasa (2015). Dalam penelitiannya Pasasa menyatakan bahwa kemajuan teknologi dan media internet menyediakan begitu banyak peluang untuk mewartakan Injil. Namun pewartaan injil melalui media internet tetap harus diatur dan dikelola dengan baik agar dapat maksimal penggunaannya. Berdasarkan pada hal itu maka penelitian ini akan melihat bagaimana pemanfaatan perkembangan teknologi dan media internet melalui aplikasi dan halaman Facebook sebagai media penginjilan pribadi.

Penelitian ini akan melihat penggunaan aplikasi "yesHeis" dalam membagikan video di media sosial Facebook serta tanggapan dari orang Kristen mengenai aplikasi tersebut. Rumusan masalah dari penelitian ini adalah "Bagaimanakah respon dan pendapat orang Kristen mengenai penggunaan aplikasi "yesHeis" dalam melaksanakan penginjilan pribadi di media sosial?" Melalui penelitian ini akan diperoleh data mengenai respon dan penggunaan aplikasi Kristen di media sosial.

\section{METODE}

Dalam penelitian ini peneliti akan menggunakan pendekatan kualitatif dengan metode analisis deskriptif agar dapat mengeksplorasi dan melihat situasi secara menyeluruh, utuh, luas dan dalam (Sugiyono, 2013, p. 290). Untuk pengumpulan datanya peneliti akan menggunakan observasi deskriptif agar dapat mendeskripsikan semua fenomena yang ditemui (Sugiyono, 2013, p. 314). Peneliti akan melihat dan mengobservasi seberapa banyak dan sering orang-orang membagikan laman "yesHeis" dalam aplikasi Facebook. Sedangkan untuk melihat respon dan pendapat orang Kristen peneliti akan mengadakan wawancara semiterstruktur yang masuk dalam kategori in-depth interview (Sugiyono, 2013, p. 318).

Peneliti mewawancarai 5 orang Kristen yang memiliki perbedaan latar belakang pekerjaan namun mereka menggunakan telepon pintar dalam kesehariannya dan aktif di media sosial, khususnya Facebook. Tiga partisipan bekerja dalam bidang pendidikan, dua partisipan lainnya adalah pengusaha muda. Para partisipan ini adalah orang-orang Kristen yang aktif dalam pelayanan di Gereja. Bahkan tiga dari partisipan telah membuka pelayanan persekutuan Oikumene. Empat partisipan berpendidikan S1 sedangkan satu orang partisipan berpendidikan S2, namun mereka tidak berasal dari Teologi. Wawancara dilakukan di kota Salatiga setelah para partisipan pulang dari pekerjaannnya masing-masing. Berdasarkan data tersebut akan dapat dilihat bagaimana respon dan juga penggunaan aplikasi "yesHeis" dalam penginjilan pribadi.

\section{HASIL DAN PEMBAHASAN}

\section{Aplikasi "yesHeis" Sebagai Media Penginjilan Pribadi}

Aplikasi "yesHeis" merupakan sebuah halaman internet yang meiliki alamat pada https://id. yesheis.com/id/.

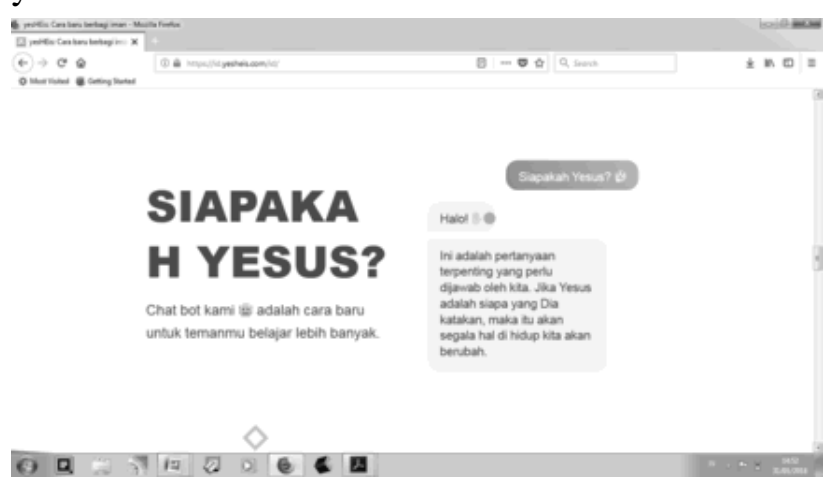

Gambar 1. Salah Satu Tampilan Laman "yesHEis"

Aplikasi ini merupakan aplikasi lokal buatan orang Indonesia. Selain daripada aplikasi online pada halaman tersebut terdapat pula halaman "yesHeis" pada media sosial Facebook. Aplikasi ini juga bisa ditemui di platform Android maupun IOS. Jadi jika seseorang sudah mengunduh dan menginstal aplikasi 
ini di perangkat telepon pintarnya, dia bisa langsung menggunakan aplikasi tersebut tanpa harus membukanya melalui internet lagi. Namun tentu saja untuk dapat menjalankan aplikasi ini dibutuhkan sambungan internet pada gawai yang dimiliki.

Dikutip dari halaman web https://id.yesheis. com/id/, tujuan pembuatan "yesHeis" adalah untuk membantu orang percaya hidup dalam misi. Aplikasi "yesHeis" memiliki berbagai fitur untuk berbagi iman. Fitur yang ada adalah fitur berbagi video dan tulisan. Adapun video yang disediakan adalah video pengalaman pribadi bersama Yesus dan juga tulisantulisan pengalaman. Bahkan pengguna juga dapat membagikan video yang dibuatnya sendiri sebagai kesaksian pribadi. Melalui aplikasi ini setiap pengguna dapat membagikan baik kisah hidupnya maupun kisah hidup orang lain pada banyak orang. Pada prinsipnya fitur yang ada di halaman web, Facebo$o k$, dan pada telepon pintar semuanya sama. Video maupun tulisan yang ada di "yesHeis" dapat dibagikan melalui beberapa situs media sosial, seperti $\mathrm{Fa}$ cebook, Instagram, Youtube dan Line. Harianto GP (2012, p. 35) menjelaskan bahwa internet termasuk video yang dimuat di dalamnya merupakan media komunikasi masa. Lebih lanjut Harianto GP (2012, p. 47) menjelaskan bahwa media komunikasi seperti video memiliki kelebihan yaitu cocok untuk menjangkau banyak orang yang tersebar luas, tetapi mahal dari sisi operasional. Dari uraian Harianto GP jelas bahwa aplikasi "yesHeis" yang memuat video dapat menjadi aplikasi yang menjangkau orang banyak.

\section{Aplikasi dan Halaman "yesHeis"}

"yesHeis" merupakan aplikasi berbagi video kesaksian Kristen di media sosial. Berdasarkan pengamatan yang telah dilakukan ada sekitar 1 juta unduhan untuk aplikasinya di telepon pintar sedangkan untuk halaman Facebook ada sekitar 900 ribu orang menyukai halamannya. Bila dilihat dari data tersebut maka cukup banyak orang-orang yang menyukai dan mengunduh halaman "yesHeis". Namun jika dibandingkan dengan data pengguna internet di
Indonesia oleh Kominfo (Wicaksono, 2014) maka presentase jumlahnya bahkan belum mencapai $5 \%$. Berdasarkan hal tersebut maka bisa dilihat aplikasi atau laman Facebook-nya belum terlalu populer.

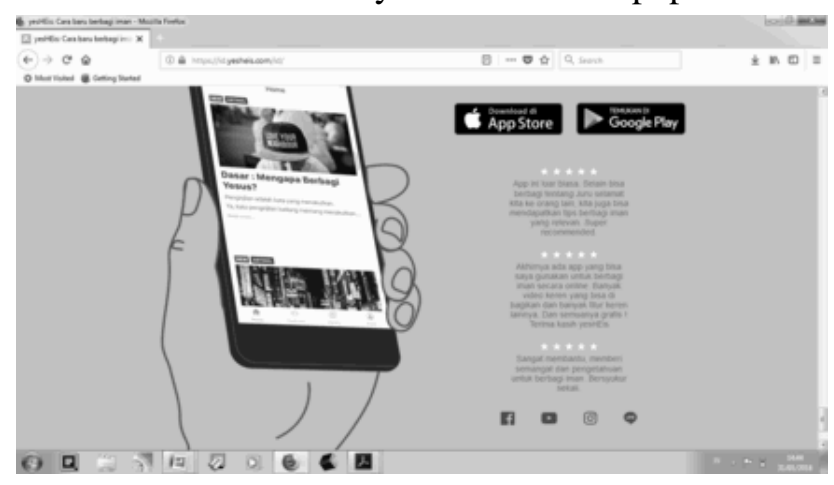

Gambar 2. Aplikasi "yesHEis"

Dari hasil wawancara yang peneliti lakukan dengan 5 orang Kristen yang aktif di media sosial dengan latar belakang yang berbeda maka didapatilah bahwa kelima partisipan tersebut tahu mengenai aplikasi dan laman Facebook "yesHeis". Namun dari kelima partisipan didapati hanya satu orang yang memiliki aplikasi "yesHeis" di telepon pintarnya sedangkan yang lainnya tidak memilikinya. Dari kelima orang tersebut juga hanya ada dua orang yang pernah membagikan video dan artikel yang ada di "yesHeis" tersebut. Sisa tiga orang bahkan belum pernah membuka artikel atau video di halaman tersebut. Yang menarik ketiga orang ini mengetahui aplikasi dan halaman "yesHeis" ini sebagai media berbagi iman. Ketika peneliti mengajukan pertanyaan para partisipan menjawab bahwa mereka mengetahuinya dari iklan yang ada di media sosial Facebook maupun iklan ketika mereka membuka situs-situs tertentu. Hal ini membuktikan bahwa promosi yang dilakukan "yesHeis" tergolong gencar sebab banyak orang yang mengetahui mengenai aplikasi dan lamannya. Namun tidak banyak yang membuka ataupun membagikan isinya.

\section{Respon dan Pendapat Atas "yesHeis"}

Berdasarkan observasi yang dilakukan maka didapati bahwa terdapat beberapa respon positif atau testimoni (kesaksian) mengenai "yesHeis" ini. Jika melihat di aplikasi telepon pintar banyak pengun- 
duhnya yang memberikan penilaian yang baik mengenai aplikasi ini. Aplikasi ini juga mendapatkan bintang hampir sempurna dari para pengunduh. "Bintang" dalam sebuah aplikasi menunjukkan seberapa baik atau buruknya sebuah aplikasi. Semakin tinggi bintangnya semakin baik aplikasi tersebut menurut pengunduhnya. Untuk halaman Facebook nya banyak yang memberikan komentar dan respon positifnya. Meskipun ada juga yang memberikan penilaian yang kurang namun sebagian besar tetap memberikan penilaian yang baik untuk halaman dan aplikasi “yesHeis".

Berdasarkan hasil wawancara didapati bahwa ada tiga orang yang memberikan respon dan komentar yang positif, sementara dua orang lainnya menganggap aplikasi ini kurang berhasil. Tiga orang yang memberikan respon positif ini berpendapat bahwa aplikasi ini dapat membantu untuk menyebarkan video kesaksian dalam berbagi iman melalui media sosial. Namun menariknya ketika ditanyakan lebih lanjut apakah ketiga orang ini akan menggunakan aplikasi "yesHeis" dalam berbagi iman hanya ada satu orang yang menyatakan ya namun dua orang lainnya menyatakan akan berpikir ulang. Ketika peneliti menanyakan pada partisipan yang pernah membagikan video dari "yesHeis" apakah respon dari teman-teman di Facebook-nya maka didapatilah bahwa hanya ada beberapa orang yang menyukai video tersebut, bahkan tidak ada komentar ataupun orang yang membagikan ulang video tersebut. Dua orang yang memberikan respon negatif menyatakan bahwa mereka sama sekali tidak tertarik akan aplikasi ini, walaupun mereka mengetahui fungsi dan kegunaan aplikasi ini. Mereka bahkan menyatakan bahwa mereka lebih baik membaca atau mengikuti akun gosip seperti "lambe turah" daripada melihat aplikasi ataupun halaman "yesHeis". Ketika peneliti menanyakan lebih lanjut mengapa mereka memberikan pernyataan tersebut maka kedua partisipan ini menyatakan bahwa aplikasi dan halaman ini kurang menarik bahkan kurang jelas tujuannya. Lebih lanjut mereka juga menyatakan bahwa video ataupun artikel yang ada kurang bisa menarik per- hatian mereka dan cenderung biasa saja. Beberapa tagline dari "yesHeis" juga terkesan biasa saja menurut kedua partisipan ini. Berdasarkan dari respon yang ada maka bisa dilihat bahwa kebanyakan orang memberikan respon yang positif dan menyambut baik aplikasi dan halaman "yesHeis". Hanya ada sedikit orang yang memberikan respon yang negatif. Namun begitu walaupun kebanyakan orang memiliki respon yang positif mereka tidak serta merta akan membagikan atau bahkan ikut berpartisipasi memberikan video kesaksian iman mereka melalui "yesHeis".

Peneliti lebih lanjut menanyakan apakah yang bisa dilakukan oleh "yesHeis" agar bisa menjangkau lebih banyak orang lagi. Kelima partisipan menyatakan bahwa aplikasi ini sebaiknya mengembangkan ulang berbagai macam isinya agar lebih menarik. Lebih lanjut mereka menyatakan bahwa aplikasi ini bisa lebih berkembang lagi asal sesuai dengan perkembangan jaman yang ada. Hal ini menandakan bahwa respon masyarakat akan lebih baik lagi ketika ada relevansi dengan kebutuhan yang ada di masyarakat. Harapan dari partisipan sejalan dengan apa yang dikemukan oleh Harianto GP (2012, p. 122) bahwa ide yang dikomunikasikan dalam satu media harus dipahami oleh para komunikan, untuk itu media komunikasi perlu disusun dengan menarik.

Para partisipan yang memberikan respon negatif juga menyatakan bahwa aplikasi ini terlalu jelas dalam menyebarkan pesan Iman Kristen. Mereka beranggapan bahwa pesan yang terlalu jelas tersebut malah dapat menimbulkan stigma atau prasangka yang kurang baik bagi orang yang belum percaya. Lebih lanjut salah satu partisipan juga mengungkapkan pengalaman hidup masing-masing orang berbeda, dengan mendengarkan kesaksian satu orang belum tentu hal itu akan terjadi pada orang yang lain. Untuk itu diperlukan relevansi yang sesuai dengan kebutuhan.

\section{KESIMPULAN}

"yesHeis" merupakan salah satu aplikasi Kristen di Indonesia, cukup banyak masyarakat yang 
memberikan respon positif atas aplikasi ini, terbukti dengan banyaknya orang yang mengunduh aplikasi ini di telepon pintar mereka dan menyukai halaman Facebook-nya. Walaupun jumlah pengunduhnya bahkan tidak mencapai 5\% dari pengguna internet di Indonesia tetap saja jumlah unduhan atas aplikasi ini cukup besar mengingat aplikasi ini bukan merupakan aplikasi umum. Banyaknya jumlah orang yang menyukai halaman Facebook "yesHeis" juga membuktikan halaman ini cukup populer di Facebook. Banyak orang yang mengetahui aplikasi ini tanpa mengunduh atau menyukainya membuktikan bahwa promosi yang dilakuakn "yesHeis" cukup gencar dilakukan di Internet.

Banyak orang yang mengetahui aplikasi ini tanpa mengunduh atau menyukainya membuktikan bahwa promosi yang dilakukan "yesHeis" cukup gencar dan masif dilakukan di Internet dan media sosial. Namun begitu hal ini tidak serta merta menimbulkan respon positif dari orang yang melihat promosi tersebut. Terbukti hanya dua dari lima orang yang pernah membuka aplikasi dan laman tersebut. Lebih lanjut didapati pula berdasarkan pengakuan dua partisipan, kalimat dalam promosi yang ada di "yesHeis" terlalu tendensius ke arah halhal yang bersifat keagamaan. Hal ini menunjukkan bahwa promosi yang gencar di dalam media sosial apabila bersifat tendensius ke arah hal keagamaan tidak selalu akan mendapatkan respon yang positif dari semua pihak. Para warga net malah justru akan menghindari hal tersebut.

Berdasarkan hasil wawancara dan observasi atas komentar dan respon mengenai aplikasi ini

\section{DAFTAR RUJUKAN}

Diaz, Bhartolomeus. 2014. "Konsep Amanat Agung Berdasarkan Matius 28:18-20 Dalam Misi”. Jurnal Koinonia, 8 (2): 15-45.

GP, Harianto. 2012. Komunikasi dalam Pemberitaan Injil. Yogyakarta: Andi.

Ismarani, D. Youth Manual. April 24, 2017. https://www.youthmanual.com/post/fun/didyou-know/data-pengguna-internet-tahun- tanggapan positif lebih banyak diberikan daripada tanggapan yang negatif. Namun begitu walaupun banyak yang memberikan respon positif tidak banyak orang yang mau membagikan video ataupun isi dari aplikasi maupun halaman Facebook nya. Hal ini menjadi sebuah bias ketika ada orang yang secara positif merespon aplikasinya namun masih ragu untuk membagikan bahkan menginstalnya di telepon pintarnya. Beberapa respon negatif atas aplikasi ini adalah karena beberapa orang tidak mendapati aplikasi ini menarik atau sesuai dengan kebutuhan mereka.

Untuk aplikasi dan laman "yesHeis" maka dapat dilaksanakan evaluasi agar melihat apa yang kurang dari aplikasinya. "yesHeis" juga dapat melaksanakan penilaian maupun FGD untuk mengetahui respon masyarakat atas aplikasinya, sehingga aplikasi ini dapat menjangkau lebih banyak orang dan melaksanakan Amanat Agung dari Tuhan Yesus di era globalisasi ini. Aplikasi "yesHeis" juga bisa mencari apa yang relevan dan dibutuhkan oleh generasi global sekarang ini. Masih banyak kekurangan dalam penelitian ini, maka dalam penelitian selanjutnya dapat dilihat hubungan dan relevansi antara aplikasi penginjilan modern; baik "yesHeis" maupun lainnya dengan relevansi dan kebutuhan masyarakat. Penelitian selanjutnya juga dapat mencari tahu mengenai kenapa ada bias dalam beberapa orang yang memberikan respon positif atas aplikasi ini namun merasa ragu untuk membagikan atau menginstal aplikasinya. Beberapa saran tersebut dapat dilaksanakan terkait dengan penelitian di masa yang akan datang.

2017-dan-apa-kesimpulan-yang-bisa-diambil-dari-data-tersebut (accessed 1, 2018).

Macaulay, J.C., and Robert H. Belton. 1956. Penginjilan Pribadi. Chicago: Moody Press.

Objantoro, E. 2017. "Sejarah Dan Pemikiran Kaum Injili Di Tengah-Tengah Perubahan dan Tantangan Zaman”. Evangelikal: Jurnal 
Teologi Injili dan Pembinaan Warga Jemaat, 1 (2): 129-138.

Pasasa, A. 2015. "Pemanfaatan Media Internet Sebagai Media Pemberitaan Injil." Jurnal Simpson: Jurnal Teologi dan Pendidikan Agama Kristen, 2 (1): 71-98.

Sawadogo, J. B. 1978. Penginjilan Pribadi. Malang: Gandum Mas.

Sugiyono. 2013. Metode Penelitian Kombinasi. Bandung: Alfabeta.

Sumolang, Marcelino. 2013. "Peranan Internet Terhadap generasi Muda". Jurnal Acta Diurna, 2 (4).
Wicaksono, Hidayat. "Pengguna Internet Indonesia Nomor Enam Dunia”. Kominfo. November 11, 2014. https://kominfo.go.id/content/ detail/4286/pengguna-internet-indonesia-nomor-enam-dunia/0/sorotan_media (accessed 1, 2018).

Wijaya, P. A., \& Darmawan, I. P. 2016. "Pembekalan Pendekatan Penginjilan Di GKII Gerizim Nusa Dua”. Prosiding Seminar Nasional PAK dan call for papers (pp. 52-57). Ungaran: Sekolah Tinggi Teologi Simpson. 